\title{
A rare case of spontaneous expulsion of a very large fibroid
}

\author{
Shaily Agarwal $^{1 *}$, Renu Gupta ${ }^{1}$, Neena Gupta ${ }^{1}$, Apurva Agarwal $^{2}$ \\ ${ }^{1}$ Department of Obstetrics \& Gynaecology, ${ }^{2}$ Department of Anaesthesiology, GSVM Medical College, Kanpur, U.P. \\ 208002, India
}

Received: 4 June 2013

Accepted: 15 June 2013

*Correspondence:

Dr. Shaily Agarwal,

E-mail: drspourush@gmail.com

(C) 2013 Agarwal S et al. This is an open-access article distributed under the terms of the Creative Commons Attribution Non-Commercial License, which permits unrestricted non-commercial use, distribution, and reproduction in any medium, provided the original work is properly cited.

\begin{abstract}
Leiomyomas are the most common benign tumour of uterus and affect 5-20\% of females. Approximately 5\% of leiomyomas are of submucous types. Usually they are asymptomatic. Symptomatic leiomyomas are managed with either medical therapy or surgical management in the form of myomectomy or hysterectomy. We are reporting an interesting and rare case of a large submucous fibroid which was spontaneously expelled per vaginally during clinical examination.
\end{abstract}

Keywords: Submucous leiomyoma, Fibroid, Expulsion, Fibroid polyp

\section{INTRODUCTION}

Leiomyoma are generally benign neoplasm and affect 5 $20 \%$ of women in reproductive age group. Submucous fibroids usually present with menstrual irregularity like menometrorrhagia, many a times it can cause recurrent pregnancy loss and infertility. We are reporting an interesting case of a large submucous fibroid polyp which spontaneously expelled during clinical examination.

\section{CASE REPORT}

A 40 years old female para one presented in emergency department with something coming out per vaginum and bleeding per vaginum for past two days following history of fall. Her menstrual cycles were normal without any history of menorrhagia or metrorrhagia. In obstetric history she had one full term normal delivery 17 years back. After that she had not conceived, but there was no history of infertility treatment. There was no history suggestive of fever or any infection.

On general examination: PR-110/min, BP-100/60mmHg, RR-32/min, Pallor-severe, Temp-101.2 ${ }^{\circ} \mathrm{F}$. On examination abdomen was soft and non tender. On local examination a large $(14 \times 15 \mathrm{~cm})$ friable, foul smelling mass bluish purple in color, soft in consistency was coming out of vagina with excessive bleeding per vaginum. The mass expelled out spontaneously during examination, after that bleeding stopped. On per speculum examination cervix was hypertrophied with circumoral erosion. Per vaginum - uterus retroverted, parous size with free fornices. Mass was sent for histopathological examination which revealed it was a leiomyoma showing red degenerative changes. After expulsion of mass USG was done which revealed normal sized uterus with empty cavity and bulky cervix and mild hydronephrotic changes were evident on both sides which disappeared on repeat scan on fifth day. Other reports were $\mathrm{Hb}-5 \mathrm{gm} \%$, TLC 16,500cells/mm, DLC P86, L8, M2, E4, B0.ESR-63mm/hr. Liver and kidney function tests were normal. Urine showed fungal colonial growth. Cervical biopsy was taken which revealed chronic cervicitis. Patient was managed conservatively with intravenous antibiotic, antifungal agent and three units of blood transfusion and was discharged satisfactorily on sixth day. 


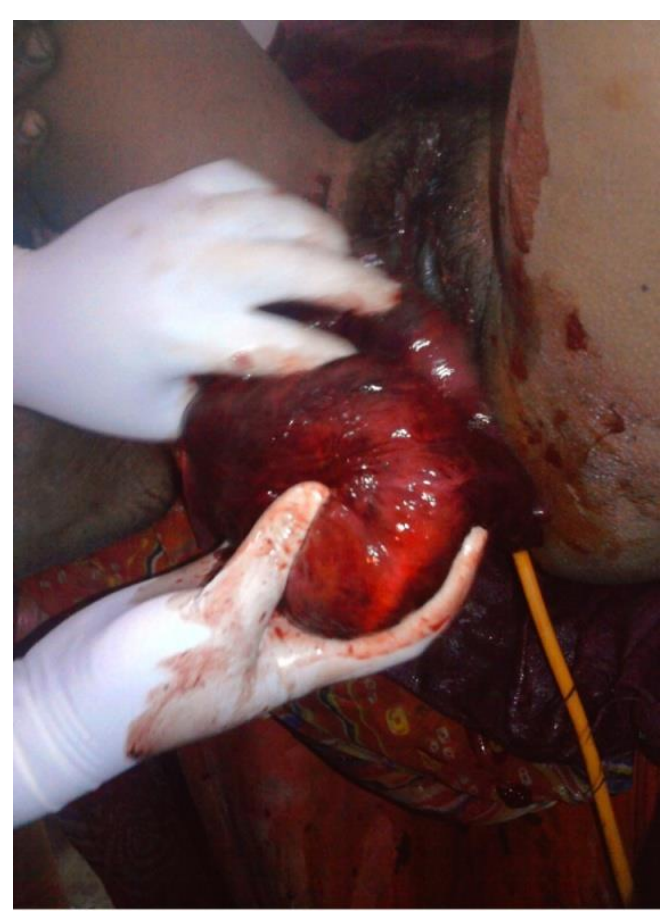

Figure 1: Showing spontaneous vaginal expulsion of large submucous fibroid.

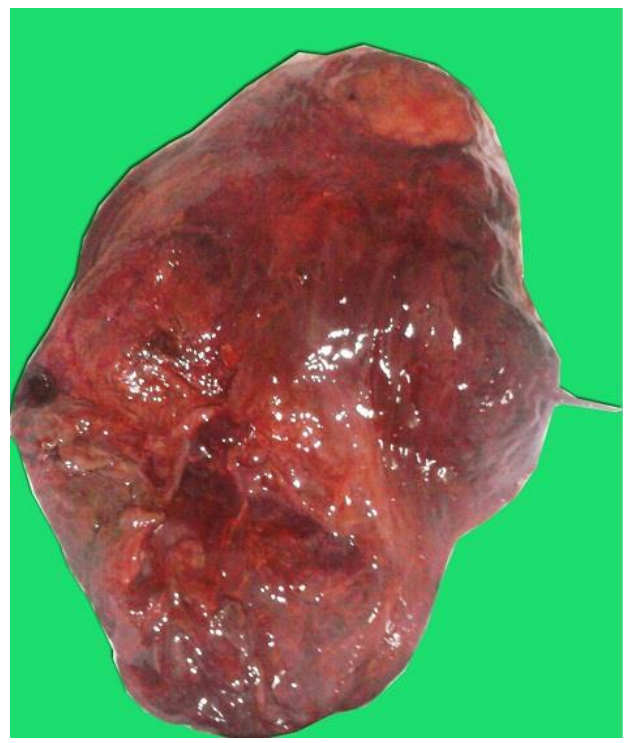

Figure 2: Submucous fibroid $(14 \times 15 \mathrm{~cm})$.

\section{DISCUSSION}

Submucous leiomyomas usually present with menstrual irregularities like menorrhagia, polymenorrhagia, metrorrhagia or intermenstrual bleeding. Sometimes they can cause recurrent pregnancy loss or even infertility. But our patient did not have any menstrual complaint which is very unusual for such a large fibroid.

Red degeneration of uterine myoma mostly develops during pregnancy and puerperium. The myoma becomes tense and tender and causes severe pain in abdomen with constitutional upset and fever, the tumor assumes a purple red color and develops a fishy odor. Our patient did not have any history of recent pregnancy, although red degeneration is sometimes reported in women over the age of 40 years as was in our case. ${ }^{1}$

Usual management in such case is removal of pedunculated submucous fibroid after ligating the pedicle but spontaneous expulsion of such a large fibroid is very rare. Although vaginal expulsion of submucous myomas after laparoscopic assisted uterine depletion ${ }^{2}$ and after uterine artery embolisation ${ }^{3}$ has been reported in literature.

\section{REFERENCES}

1. Weston Gareth and Healy David L, Uterine fibroids, Shaw R W, Leusley D, Monga A. Gynecology 4rth edition, Gurgaon, Reed Elsevier India Pvt. Itd, 2010; 473-487.

2. Liu WM, Yen YK, Wu YC, Yuan CC, Ng HT. Vaginal expulsion of submucous myoma after laparoscopic assisted uterine depletion of the myoma. J Am Assoc Gynaecol Laparsc 2011;8(2):267-271.

3. Vural B, Ozkan S, Ciftçi E, Bodur H, Yücesoy I. Spontaneous vaginal expulsion of an infected necrotic cervical fibroid through a cervical fistula after uterine artery embolization: a case report. J Reprod Med. 2007 Jun;52(6):563-6.

DOI: $10.5455 / 2320-1770 . \mathrm{ijrcog} 20130942$

Cite this article as: Agarwal S, Gupta R, Gupta N, Agarwal A. A rare case of spontaneous expulsion of a very large fibroid. Int J Reprod Contracept Obstet Gynecol 2013;2:449-50. 